Comparative Philosophy Volume 9, No. 1 (2018): 18-31

Open Access / ISSN 2151-6014

www.comparativephilosophy.org

\title{
THE YOGĀCĀRA THEORY OF THREE NATURES: INTERNALIST AND NON-DUALIST INTERPRETATION
}

\author{
MATTHEW MACKENZIE
}

\begin{abstract}
According to Vasubandhu's Trisvabhāvanirdeśa or Treatise on the Three Natures, experiential phenomena can be understood in terms of three natures: the constructed (parikalpita), the dependent (paratantra), and the consummate (parinișpanna). This paper will examine internalist and anti-internalist or non-dualist interpretations of the Yogācāra theory of the three natures of experience. The internalist interpretation is based on representationalist theory of experience wherein the contents of experience are logically independent of their cause and various interconnected cognitive processes continually create an integrated internal world-model that is transparent to the cognitive system that creates and uses it. In contrast, the anti-internalist interpretation begins, not from the constructed nature of experiential objects, but from the perfected nature of mind-world non-duality. This interpretation treats the distinctions between inside and outside, subject and object, mind and world as distinctions drawn within experience rather than between experience and something else. And experience here refers to the continuous dynamic interplay of factors constituting our sentient embodied (nāma-rūpa) existence. Having examined each interpretation, the paper will suggest some reasons to favor the non-dualist view.
\end{abstract}

Keywords: Yogācāra, Buddhist idealism, internalism, non-dualism, three natures of phenomena, Vasubandhu, solipsism

\section{INTRODUCTION}

According to Vasubandhu's Trisvabhāvanirdeśa or Treatise on the Three Natures, experiential phenomena can be understood in terms of three natures (svabhāva) and three forms of naturelessness (nihsvabhāvatā). The three natures are the fabricated or constructed nature (parikalpita-svabhāva), the dependent nature (paratantrasvabhāva), and the perfected or consummate nature (parinispanna-svabhāva). This paper will examine internalist and non-dualist (or anti-internalist) interpretations of

MACKENZIE, Matthew: Associate Professor of Philosophy, Colorado State University, Colorado, USA. Email: matt.mackenzie@colostate.edu 
The Yogācāra theory of the three natures of experience. The primary form of interpretation here is philosophical. That is, my main concern is with the rational reconstruction of certain central Yogācāra philosophical commitments. The internalist interpretation is based on a representationalist ${ }^{1}$ theory of experience wherein the contents of experience are logically independent of their cause and various interconnected cognitive processes continually create an integrated internal worldmodel that is transparent to the cognitive system that creates and uses it. In contrast, the anti-internalist interpretation begins, not from the constructed nature of experiential objects, but from the perfected nature of mind-world non-duality. This interpretation treats the distinctions between inside and outside, subject and object, mind and world as distinctions drawn within experience rather than between experience and something else. And experience here refers to the continuous dynamic interplay of factors constituting our sentient embodied (nāma-rūpa) existence. Having examined each interpretation, I will suggest some reasons to favor the non-dualist view.

\section{THE THREE NATURES OF PHENOMENA}

In the opening verses of Treatise on the Three Natures Vasubandhu explains:

1. Fabricated, dependent and perfected: So the wise understand, in depth, the three natures.

2. What appears is the dependent [paratantra]. How it appears is the fabricated [parikalpita]. Because of being dependent on conditions. Because of being only fabrication.

3. The eternal non-existence of the appearance as it appears: That is known to be the perfected nature [parinispanna-svabhāva], because of being always the same.

4. What appears there? The unreal fabrication. How does it appear? As a dual self. What is its nonexistence? That by which the nondual reality is there. (Gold 2014, 244)

'The fabricated' (parikalpita) here connotes mental construction and to say that an experiential object has a fabricated or constructed nature in this sense is to point to the way in which the object qua experienced depends on the constructive activities of mental processes. It is a core claim of the Yogācāra approach that objects of experience can only appear through the constructive activity of cognition and that this activity makes an essential contribution to how the empirical object is given. Thus, to say that an object is mentally constructed is not to say that it is a mere hallucination, since any object of experience is constructed in this way. Yet, the fabricated nature is

\footnotetext{
${ }^{1}$ The term 'representationalism' is ambiguous in contemporary philosophy. Here I am using it in the older, broadly Lockean sense, associated with, for instance, indirect realist views of perception.
} 
inherently misleading in that, in normal experience, we do not experience objects as mentally constructed. Rather, our default mode is a form of naïve realism that takes the mind to present objects as they really are independently of the contribution of the mind. This leads to the paratantra-svabhavva, the dependent nature of phenomena. Despite the fact we tend to experience objects as experience-independent, on the Yogācāra account, they depend on constructive mental activity. The rainbow qua experiential object depends on the sensory-cognitive systems of perceivers like us. Since the object as a construct is not pre-given in its conditions, our deep sense that cognition is the simple mirroring or recovery of pre-given objects of experience is mistaken. The deeper truth, on this analysis, is the absence of the constructed nature from the dependent nature. Finally, the parinișpanna-svabhāva, the perfected nature, is the true or undistorted nature of phenomena. This is understood in terms of how an enlightened being would experience phenomena, namely, as the dependent nature absent the distortions inherent in the constructed nature, most fundamentally the subject-object dichotomy.

Minimally, on the Yogācāra analysis, we start out as naïve realists about the experienced world (including our own subjectivity), but through careful analysis we can come to see clearly the ways in which our experience of the world and ourselves is dependent on our own mental processes. But the Yogācārins go further. As Vasubandhu boldly asserts in the Vimśatika or Twenty Verses, "Everything in the three realms is only appearance." "The three realms' here refers to the worlds or states of being into which sentient beings are born. Thus the shared phenomenal worlds of sentient beings are appearance-only (vijūāpti-mātra). And this means, Vasubandhu makes clear in his auto-commentary, that the three realms are nothing but citta and caitta (mental processes and their variegated qualities or factors) and there are no mind-independent objects (artha). In so far as reality can be positively characterized at all, it is cittamatra, mentality-only or experience-only. ${ }^{3}$ Experiential objects, then, are immanent to experience, despite appearing as independent of experience. The fabricated appearance of independent subjects and objects is a distortion of the non-dual flow of experience. As he puts in the Trimsika (Thirty Verses), "The metaphors of self and external phenomena, functioning in various ways, take place in the transformation of consciousness." And in Trisvabhāvanirdeśa 5 , he writes, "What is this unreal fabrication? Mind. For it does not exist at all in the way it is fabricated or in the way it fabricates a thing" (Gold 2014, 244). Indeed, Vasubandhu famously likens the distortion to a persistent perceptual illusion-the appearance of hairs in the visual field of one with an eye disease. This commitment to the radical primacy of experience is also found in William James' radical empiricism. As James puts it in "Does Consciousness Exist?":

\footnotetext{
2 traidhātukam vijnaptimātram vyavasthāpyate.

${ }^{3}$ I use 'experience' or 'mentality' for citta because I think, for the Yogācārins, the term covers a far broader range of phenomena than our term 'consciousness'.

${ }^{4}$ àtmadharmopacāro hi vividho yaḥ pravartate vijñānapariṇāme’ sau (1a-c).
} 
As 'subjective' we say that the experience represents; as 'objective' it is represented. What represents and what is represented is here numerically the same; but we must remember that no dualism of being represented and representing resides in the experience per se. In its pure state, or when isolated, there is no self-splitting of it into consciousness and what the consciousness is 'of.' Its subjectivity and objectivity are functional attributes solely, realized only when the experience is 'taken,' i.e., talked-of, twice, . . . The instant field of the present is at all times what I call the 'pure' experience. It is only virtually or potentially either object or subject as yet. For the time being, it is plain, unqualified actuality, or existence, a simple that. (James 1976, 13)

In what follows, I will take for granted the Yogācāra commitment to the primacy of experience, while examining internalist and anti-internalist interpretations of it.

\section{THE INTERNALIST-REPRESENTATIONALIST VIEW}

One way to flesh out the Yogācāra view is in the direction of an internalistrepresentationalist account of mind. This account fits well the historical and conceptual connections between Vasubandhu's Yogācāra and the indirect-realist and representationalist views propounded in the Sautrāntika school. It also makes good sense of some of Vasubandhu's arguments against naïve and direct realist accounts of the mind. Another way to flesh out the model of the three natures is in the direction of a more radically non-dualist account of experience. This account makes good sense of Vasubandhu's emphasis on overcoming subject-object duality and on the flow of experience as fundamental.

The internalist-representationalist interpretation is based on a representational theory of experience wherein the contents of experience are logically independent of their cause. So, in the familiar fashion, an experience can be a visual presentation as of a shiny red apple, whether that experience is a dream, a hallucination, or a veridical perceptual experience. Indeed, what we are directly aware of in experience are not external objects, but mental images or representations ( $\bar{a} k \bar{a} r a)$, which can be caused in a variety of ways. Dreaming and perception alike involve the phenomenal presentation of experiential objects, but differ in their causal constraints. As Vasubandhu argues in the Vimśatik $\bar{a}$, those general features of waking experience that the realist attributes to interaction with experience-independent objects can also be found in dreams, which both parties admit do not involve the apprehension of independent objects.

Restriction as to place, etc. is demonstrated as in a dream. (3a) Now how is this? In a dream, even without an (external) object of sense or understanding, only certain things are to be seen: bees, gardens, women, men, etc. and these only in certain places, and not everywhere. And even there in those places, they are to be seen only sometimes, and not all the time. In this way, even without an (external) object of sense or understanding, there may be restriction as to place and time (Anacker 1998, 162). 
Moreover, the character of a representation derives from the capacities and conditioning of the mind that creates it. Thus, depending on the differences in their karmic conditioning, one being will experience crystal clear water, while another experiences a river of pus. "For all the pretas who are in a similar situation due to a similar retribution for action, and not just one of them, see a river filled with pus" (Anacker 1998: 162). This extreme difference in experiential contents is not explained by appeal to independently existing objects.

The stream of consciousness, then, is a causal process whereby virtual worlds of experience are brought forth moment by moment. The citta-samtāna is in the business of dreaming up worlds of experience, whether we are asleep or awake. Yet, we are by default naïve realists about the virtual worlds our minds create. We do not recognize our mental constructs as mental constructs, but take them to be mindindependent external objects. Thus the fabricated nature here refers to the mentally constructed objects within the virtual world of experience. The dependent nature refers to the fact that, despite appearances, experiential objects are mind-dependent (both causally and constitutively). The dependent nature by extension also refers to those causal processes by which mental objects are constructed. Recognition of the absence of the constructed nature from the other dependent nature amounts to a recognition that the direct objects of experience are merely mental constructs or representations (vijñāptimātra) that continuously emerge from causal processes that we are not directly aware of. Seeing through to the true nature of experience, finally, is to experience the perfected nature.

On the Yogācāra account, this recognition of the true nature of experience is not a merely intellectual understanding, but rather a transformation at the very basis of experience (áśraya-parāvrtti). In the normal case our mental representations are transparent -we do not see them as representations at all. As Thomas Metzinger writes, "a representation is transparent if the system using it cannot recognize it as a representation. A world-model active in the brain is transparent if the brain has no chance of discovering that it is a model" (Metzinger 2010,41). He goes on to say that our various mental representations are,

seamlessly integrated into your overall conscious space of experience. Because it has been optimized over millions of years, this mechanism is so fast and so reliable that you never notice its existence. It makes your brain invisible to itself. You are in contact only with its content; you never see the representation as such; therefore, you have the illusion of being directly in contact with the world. And that is how you become a naïve realist, a person who thinks she is in touch with an observer-independent reality. (Metzinger 2010, 43)

On the internalist-representationalist interpretation of the three natures, various interconnected cognitive processes continually create an integrated internal worldmodel that is transparent to the cognitive system that creates and uses it. Note, though, that Metzinger's account of transparency is stronger than Vasubandhu's, since Metzinger asserts that the system itself cannot recognize its transparent 
representations as representations. Vasubandhu, however, holds that our representations are in the normal case strictly transparent, but that this can change through the development of philosophical and meditative insight.

There are two interesting types of case that lend support to Vasubandhu's position. The first type of case concerns persistent auditory hallucinations. People who suffer from persistent musical hallucinations often report that the music is experienced as if it were like any other music playing in their environment. It can be experienced as loud or quiet, as nearby or far away, as clear or muffled, and so on. While some people quickly realize that they are experiencing hallucinations, others remain for extended periods under the impression that their auditory experience is veridical. According to Paul Coates (2013), the transition process follows three stages. In the 'deceptive phase', the music is experienced as externally produced, spatially located, and public. Here the auditory experience is constructed as an external sound event. Eventually, in the 'transition phase' the subject realizes that the auditory experience does not correspond to bodily movements in the right way (moving toward or away from the apparent location of the sound does not change its sensory character) or that others can't hear it, etc. In the final 'realization phase', the subject has come to fully recognize the hallucination as a hallucination. What this involves, according to Coates, is a shift in the way the auditory phenomenon is automatically conceptualized. So, while the subject can still describe the various phenomenal features of the auditory phenomena (volume, pitch, timbre, etc.), she no longer takes it to be an objective sound event. It is important to see that, on Coates' view, this is not a merely intellectual change. Rather, because our experience involves an integration of sensory and cognitive aspects, a change in how a sensory phenomenon is automatically conceptualized is a change in the overall phenomenal character of the experience. What was transparently experienced as an objective event is now experienced as an internal merely subjective event. Hence, the auditory representation is no longer transparent in Metzinger's sense.

The second type of case is lucid dreaming. In cases of lucid dreaming, subjects are dreaming, but are aware that they are dreaming and also possess memory of both waking life and dream life, as well as the experience of attentional, thinking, and behavioral agency (Metzinger 2010). The lucid dreamer recognizes the dream world as a dream world and therefore recognizes the virtual world of experience as virtual. This type of global recognition of the mind-dependent character of the dream world can also carry over into waking life such that waking is also experienced as dreamlike. On the internalist-representationalist interpretation of Vasubandhu's Yogācāraand following an analogy used in the tradition itself - the transformation at the basis (ásrayaparāortti) is similar to the global recognition found in lucid dreaming. To realize the consummate nature is to have not just lucid dreaming, but lucid experiencing as such.

Now despite the perhaps unfamiliar language, much of this should be fairly familiar. What we are directly aware of in conscious experience are not observerindependent features of the external world, but mental images caused by the interaction between a broader causal nexus and our cognitive system. We are usually 
unaware of both the constructive activity of the mind in producing these images and we are unaware that they are images, rather than external objects. The mind constructs a virtual world-model that is transparent to us. But Vasubandhu's view is more radical than many other internalist-representationalist views of the mind in that he applies the model of the three natures to the subject of experience as well. For him, the fundamental structure of the parikalpita-svabhāva is the subject-object framework itself. Like the observed objects, the observing self is a virtual construct (kalpita$\bar{a}$ tmanā) of a cognitive system. Indeed, Vasubandhu will agree with the Nyāya (and Kantian) point that there is a deep interdependence between grasping an objective world and grasping oneself as a persisting subject of experience. It's just that, on his view, this goes to show that both are distorted mental fabrications, appearance-only. On the Yogācāra view, the sense of self arises from the way the cognitive system models itself and draws the self-other distinction. This is the klișta-manas (afflictive mentation), which mistakes the selfless flow of the älayavijñanna (base consciousness) for a persisting self. It is also the basis for the general sense of mental ownership and for thinking self-referential thoughts involving 'I', 'me', and 'mine' (and their contrasts). Yet, for Vasubandhu, there is no such entity as a self, only the self-model of an impermanent cognitive system. What we take to be the self is like an avatar in the virtual world created by the mind. Again, the similarity to Metzinger is instructive:

The brain is like a total flight simulator, a self-modeling airplane that, rather than being flown by a pilot, generates a complex internal image of itself within its own internal flight simulator. The image is transparent and thus cannot be recognized as an image by the system. Operating under the condition of a naive-realistic self-misunderstanding, the system interprets the control element in this image as a nonphysical object: The "pilot" is born into a virtual reality with no opportunity to discover this fact. The pilot is the Ego. (Metzinger 2010, 108)

Of course, Vasubandhu takes the basis of the simulation to be the alayavijñanna, not the brain (and he is, to put it mildly, much less sanguine about the idea that the ultimate causal basis of experience is an observer-independent physical reality). Moreover, as we have seen, he thinks it is possible to come to see both the experiential world and the experiential self as vijñaptimātra. The result is said to be a radical transcendence of the subject-object framework of understanding experience.

This internalist-representationalist approach to Yogācāra, taken to its logical conclusion, finds expression in later Buddhist epistemologists like Ratnakīrti. The reduction of subject and object to mere virtual images internal to a moment of consciousness, coupled with Buddhist nominalism and mereological reductionism, pushes later thinkers to embrace (what has been called) solipsistic idealism. Prajñākaragupta, for instance, gives a bracing summary of this radical view:

There is neither an 'I' nor a 'he' nor a 'you' nor even an 'it'; neither the thing, nor the not-thing; neither a law nor a system; neither the terms nor the relations. But there are only the cognitive events of colourless sensations which have forms but no names. They 
are caught for a moment in a stream and then rush to naught. Even the stream is a fiction. That sensum of the moment, the purest particular, that advaya, the indivisible unit of cognition, that is the sole reality, the rest are all fictions, stirred up by time-honoured convention of language which is itself a grand fiction. (Ganguli 1963, 193)

\section{THE NON-DUALIST VIEW}

While the above internalist-representationalist interpretation of the doctrine of three natures is a coherent and plausible one, I would now like to turn to a quite different, anti-internalist or non-dualist interpretation of the trisvabhāva view. On this 'nondualist' interpretation, we start, not from the constructed nature of experiential objects, but from the perfected nature of mind-world non-duality. In this regard, Japanese philosopher Nishitani Keiji relates an interesting story from the Zen tradition:

On a pilgrimage seeking the Way with two companion monks, Hōgen stopped to rest at the temple of a Zen priest named Jizō (Dicang) one rainy day. When the rain cleared and they were about to set off again, Jizo, who had come to see them off, remarked, "It is said you usually expound the doctrine that the three worlds are mind only." Then, pointing to a rock in the garden, he asked, "Is that rock inside your mind or outside it?" "Inside my mind, of course," was the answer Hōgen gave, typical of consciousness-only theory. Jizō immediately retorted, "By what karmic fate I do not know, but a man is wandering around with a lump of stone in his mind. He must feel quite heavy." (Nishitani 2009, 101)

Jizō's point here, I take it, is not to reinstate a naively realistic view of experience, but rather to challenge Hōgen's phenomenologically and ontologically internalist view of Yogācāra. That is, the attempt to overcome the subject-object dichotomy by simply internalizing the phenomenal world-whereby the experienced rock is supposed to be in Hōgen's mind, which is implicitly in his head-is insufficiently radical. It tries to overcome the dichotomy by treating the mind as self-contained and therefore it does not transcend the subject-object or inside-outside duality, but rather absolutizes one side of it. Instead of the thoroughgoing interdependence of mind and world, the internalist-representationalist account of the three natures treats the mind as an autonomously intelligible domain. Indeed, it is precisely the tendency to treat the mind as being self-contained and ontologically fundamental (call it the myth of the 'ready-made mind') that is at the basis of Candrakīrti's Madhyamaka critique of Yogācāra.

The key to the anti-internalist interpretation is to see that Yogācāra constitutes a radical critique and revision of the notion of mentality or experience. Given our deeply entrenched realist and objectivist assumptions, it is hard to resist the idea that, in claiming that the phenomenal world is vijñäptimātra, the Yogācārins are positing experience as veil of appearances between subject and world. But this is to confuse the parikalpita with the paratantra - that is, it conflates the fabricated distortion of experience with the real nature of experience itself. Experience (vijñanna) as 
paratantra is neither a medium nor a partition between the subjective and objective realms. It is the dynamic causal process out of which subjects and objects emerge. And since there is no subject apart from this more basic causal-experiential process, the process itself cannot serve as a medium or a veil between a subject and its world.

The non-dualist alternative, then, is to treat the distinctions between inside and outside, subject and object, mind and world as distinctions drawn within experience rather than between experience and something else. And experience here refers to the continuous dynamic interplay of (what we label) 'mental' and 'physical' factors constituting our sentient embodied (nāma-rūpa) being-in-the-world. This radical view is, I think, prefigured even in the early Buddhist tradition. In the Dīgha Nikāya we find:

just this, namely namma-rūpa, is the cause, ground, origin and condition of consciousness. Thus far, then, can we trace birth and decay, death and passing away and being reborn, thus far extends the way of designation (adhivacana), of language (nirutti), of concepts

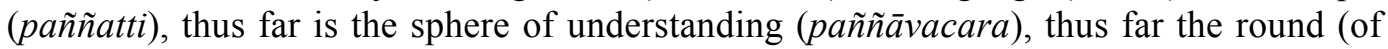
rebirth) goes as far as can be discerned here, namely nāma-rūpa together with consciousness. (Walshe 1995, 224)

In Yogācāra, we find a radically experientialist revision of this early Buddhist view. The näma-rüpa process is now seen as a causal-experiential process by which karmically recursive streams of experience - including bodily experience - give rise to the appearance of subjects-in-worlds. So, rather than holding fixed the internalistsubjectivist view of mentality and simply internalizing the phenomenal world, it would be more accurate to say that Yogācāra radically externalizes the notion of experience. The causal-experiential process of paratantra is now co-extensive with the causal nexus of dependent arising.

Thus, as I pointed out above, the anti-internalist interpretation has affinities to radical empiricism. In both radical empiricism and Yogācāra, experience is understood transactionally. As John Dewey writes:

The structure of whatever is had by way of immediate qualitative presences is found in the recurrent modes of interaction taking place between what we term organism, on one side, and environment, on the other. This interaction is the primary fact, and it constitutes a trans-action. Only by analysis and selective abstraction can we differentiate the actual occurrence into two factors, one called organism and the other, environment. (Dewey 1984 v.5, 220)

On this non-dualist interpretation of the three natures, the paratantra-svabhāva is the transactional flow of lived experience itself. From this flow we can construct (and reconstruct) the various distinctions between mind and world, subject and object, or inside and outside, but these categories should not be thought of as metaphysically prior to experience. As Dewey and Arthur Bentley further characterize the transactional approach: 
systems of descriptions and naming are employed to deal with aspects and phases of action, without final attribution to "elements" or other presumptively detachable or independent "entities," "essences," or "realities," and without isolation of presumptively detachable "relations" from such detachable "elements" (Dewey and Bentley 1989,108).

Furthermore, the construction of experiential objects and subjects is misleading in that we take the constructs to be prior to and independent of the experiential process itself. This does not mean that experiential objects are 'inside us', rather than 'out there' in the world where they appear to be. Rather, the point is that the very contrast between inside and outside emerges from and only makes sense within lived experience itself. Finally, the direct realization that there is no 'sideways-on' view of the open-ended domain of experience and therefore no absolute dualities within it is the realization of the perfected nature.

Furthermore, even at the level of the fabricated nature, there are reasons to question the strictly internalist-representationalist interpretation. Again, the basic problem with the internalist interpretation is that it preserves the idea of mentality as a self-contained, private, subjective domain and then tries to internalize the world - the phenomenal world becomes the content of a private internal world-model. This raises the specter of solipsism in that the same argumentative strategies used to undermine belief in an external world of objects independent of one's own mind can be used to undermine belief in other minds as well. This challenge was well known to later Yogācārins, such as Dharmakīrti, who attempted to show that Buddhist idealism does not entail solipsism (Henkel 2012). Yet, the internalist approach does not fully appreciate the radical decentering of the subjective, first-person point of view in Yogācāra. As Sthiramati tells us in the Madhyāntvibhāgațīkā, "Subjectivity (grāhakatvam) is not possible if no object (grāhya) exists." And, "Since there is no object in the absence of a subject, it is not possible for there to be a subject when there is no object" (Shaw 1987, 233). Within the parikalpita (or experience as abhütaparikalpita) subjectivity and objectivity are mutually specifying, and so mentality cannot be understood as an autonomous, private domain. Subjectivity and objectivity are interdependent fabrications of the process of experience, and therefore the subject is always a subject-in-a-world. So, while Vasubandhu's appeal to dreams may point to the phenomenological and explanatory robustness of the experiential process, it is his appeal to ghosts (pretas) and hell-realms that is most important to the anti-internalist interpretation.

According to the Buddhist cosmology Vasubandhu is drawing on in the Vimiśatikā, humans and pretas share a world, a bhäjana-loka or 'receptacle world'. They share an apparent physical locus and both perceive a river in the same place. However, as mentioned earlier, humans see clear water while pretas see pus. In contrast, hell-beings exist in a realm that is spatially distinct from the human realm, where they experience torture at the hands of demons. However, the demons are not independent beings in their own right, but rather collective projections of the negative karma of the poor beings in hell. The key point here, though, is that interacting causal-experiential streams co-create shared intersubjective worlds. And these shared 
worlds provide the context for on-going karmic activity, which in turn shapes the subjectivity of beings within these worlds. Hence, while dream experience may be understood as the imaginative play of an individual mind-stream, waking experience is understood as the intersubjective co-creation of shared (or overlapping) phenomenal worlds. On this account, the first-person perspective of the subject is not the privileged basis of experiential construction, but simply one more fabricated aspect of it. And individual subjectivity cannot be understood apart from intersubjectivity and shared phenomenal worlds.

Finally, it is important to appreciate the central role of conceptual-linguistic construction in the Yogācāra view. The construction of shared worlds of experience relies on the operations of various conceptual and linguistic imprints or predispositions: conceptual imprints (vikalpavāsanā), linguistic imprints (abhilāpavāsanā), and discursive imprints (prapañcavāsanā). These vāsanās are critical to the construction of shared worlds (bhajjana-loka) and are themselves intersubjective. As we see in early Yogācāra, the älayavijñāna has both individual (asādhärana) and shared or common (sädhärana) dimensions, and the conceptual and linguistic predispositions are directly associated with the common dimension. For the Yogācārins, to a large degree we share a common life-world because we share (mostly sub-personal) conceptual and linguistic schemas. This stated clearly in the Saṃdhinirmocana Sūtra:

The mind with all the seeds (älayavijñanna) matures, congeals, grows, develops, and increases based upon ... the substratum of the material sense-faculties along with their supports and the substratum which consists of the predispositions toward conceptual proliferation in terms of conventional usage of images, names, and conceptualizations.

(Waldron 2003, 95)

The individual aspect of base consciousness is largely grounded in our sensory faculties, while the shared aspect is largely grounded in our conceptual-linguistic schemes. Furthermore, these cognitive predispositions suffuse (or 'perfume') our experience and play a central role in the fabrication of our subjectivity. Thus, it isn't just our shared world that is intersubjectively constructed, human subjectivity, on this account, is also conceptually and linguistically constructed.

Returning to Coates' three phases of recognizing a hallucination, on the nondualist view, the deceptive phase is just naïve realism about lived experience. We experience ourselves as isolated Cartesian subjects confronting other Cartesian subjects within a fully independent objective world. In the transition stage, we come to deeper understanding of the constructing and constructed nature of experience. This leads to the realization stage, a recognition that subjectivity, intersubjectivity, and objectivity are thoroughly interdependent co-constructions of causal-experiential processes that are both beneath and beyond subject and object. Reality, in so far as it can be positively characterized at all, is seen-to borrow a phrase from Timothy Sprigge $(2006,484)$ — as "a vast system of interacting streams of experience," beyond all duality. 
The non-dualist view of the three natures sketched here is similar to what Anthony Rudd (2003) calls Kantian or non-realist externalism, which he attributes also to Wittgenstein, Heidegger, and Merleau-Ponty. "On the [realist] externalist views," he writes, "the mind is not self-contained; the non-realist externalist will agree with that, but will add that the world is not self-contained either" (Rudd 2003, 49). In the context of the Yogācāra dialectic, we may rephrase this as, "the world (or experiential objects) is not self-contained, but the mind is not self-contained either." Mind and world are constitutively bound together and there is no point of view completely outside this interdependence. What come to be labeled as 'mind' and 'world' are momentary constructions carved out of the dynamic, interdependent flow of the paratantra. As Sthiramati puts it, "Indeed, consciousness takes on the appearance of manifold images, in the form of all sorts of independent things, like the eyes in the tail of a peacock... (but) the independent elements (dharmasvabāvah) ... are merely illusion (bhrāntimātra)" (Shaw 1987, 233).

But, one might object in Candrakīrtian fashion, if we cannot step outside of lived experience and it is that from which 'subject' and 'object', etc. emerge, then hasn't experience itself been absolutized? In a sense, this is what we find in Ratnakīti's Saṃtānāntara-dūṣaṇa (Refutation of Other Mindstreams):

If the mind of another person is possibly existent, then our own mind would be differentiated from that; otherwise what is admitted as another mind would not be distinct from our own mind which is being manifested. But we do not actually discern the difference between the two. Thus, it follows that another person's mind, which is excluded neither from what is different from our own mind, nor from what is identical with it, is simply non-existent as a universal (sāmānya) or a rabbit's horn. (Kajiyama 1965, 425-426)

In Ratnakīrti's Yogācāra, while one may differentiate one's own mind from others at the conventional level, at the ultimate level there is no real boundary (avadhi) between streams of experience (Perrett 2017). There is only non-individuated, absolute mind or consciousness.

However, the anti-internalist Yogācārin, in response to the Candrakītian objection, could say that 'experience' (citta-caitta) itself should be treated as a transactional (vyavahāra) notion not an absolute one. Vasubandhu and his fellow Yogācārins, on my interpretation, agree with the more general Mahāyāna view that reality as such (dharmatā) is inexpressible, a "thusness" (tathatā) that cannot be captured by any conceptual framework, including the conceptual framework of cittamátra. At the conventional level, the causal-experiential process has a kind of primacy insofar as it is the always-presupposed background of our more particular practices of understanding and explanation. But precisely insofar as it plays its role as background, it cannot also serve as an epistemic or absolute ontological foundationthough perhaps some Yogācārins wanted it to do so. It seems to me that to try to employ experience foundationally, though, would be to try to objectify that which 
makes possible and thus always recedes from objectification. In this sense, experience is both inescapable and ultimately ungraspable.

\section{CONCLUSION}

I have argued that the internalist-representationalist account fits the historical and conceptual connections between Yogācāra and the indirect-realist and representationalist views propounded in the Sautrāntika school. Additionally, it makes sense of some of the key epistemological arguments against naïve and direct realist accounts of the mind and world. However, the internalist interpretation is weaker concerning Yogācāra accounts of the intersubjective co-creating of the phenomenal world, and their radical critique of subject-object duality. Furthermore, as a philosophical matter, the internalist view threatens to collapse into solipsism. While the threat of solipsism is not itself a decisive reason to reject the internalist interpretation, considerations of charity in philosophical reconstruction make it reasonable to look for alternative interpretations, especially since major Yogācāra thinkers like Vasubandhu and Dharmakīrti explicitly reject solipsism.

I have further argued that the non-dualist interpretation better accommodates the deep intersubjectivity of phenomenal worlds, the individual and shared aspects of the àlayavijñanna, and the radical non-duality of subject and object in Yogācāra. Admittedly, the non-dualist interpretation implies a greater conceptual distance between Yogācāra and Sautrāntika, which may be thought a weakness of the interpretation. Yet, the non-dual interpretation does highlight important continuities between Yogācāra and later East Asian forms of Buddhism, such as Zen (Nishitani 2009). Furthermore, the non-dualist interpretation, I think, provides a better answer to the question of solipsism and shows why Yogācāra idealism is fundamentally different from simple subjective idealism. Where subjective idealism merely internalizes the objective, reducing it to the subjective, Yogāaāra idealism offers a radical critique of both objectivity and subjectivity. Conventionally, subject and object, grasper and grasped are thoroughly interdependent. Ultimately, there is neither subject nor object, but only the flow of non-dual awareness - though even here we must remember that, for the Yogācārin, constructions like 'the flow of non-dual awareness' are only provisional pointers to what is ultimately inexpressible. In the end, if the non-dualist interpretation makes apparent that Yogācāra is neither solipsism nor subjective idealism, I take that to be a good reason to prefer it over the internalist interpretation.

\section{ACKNOWLEDGEMENTS}

I would like to thank Arindam Chakrabarti, Anand Vaidya, and Sean Michael Smith for critical discussion of an earlier version of this paper, presented at the 2017 APA Eastern Division meeting. I would also like to thank the two anonymous reviewers for this journal for helpful suggestions for improving this article. 


\section{REFERENCES}

Anacker, Stefan (1998), Seven Works of Vasubandhu (Delhi: Motilal Banarsidass).

Coates, Paul (2013), "Hallucinations and the Transparency of Perception", in F. Macpherson and D. Platchias (eds.) Hallucination: Philosophy and Psychology (Cambridge: MIT Press), 381-398.

Dewey, John (1984), "Conduct and Experience" in J. A. Boydston (ed.) The Later Works of John Dewey (Carbondale: Southern Illinois University Press), 218-235.

Dewey, John and Bentley, A. (1989) "Knowing and the Known" in J. A. Boydston (ed.) The Later Works of John Dewey (Carbondale: Southern Illinois University Press), 1-279.

Ganguli, Hemanta (1963), Philosophy of Logical Construction (Calcutta: Sanskrit Pustak Bhandar).

Gold, Jonathan (2014), Paving the Great Way (New York: Columbia University Press).

Henkel, Jeremy (2012), "How to Avoid Solipsism While Remaining an Idealist: Lessons from Berekely and Dharmakīti" Comparative Philosophy 3.1: 58-73.

James, William (1976), Essays in Radical Empiricism (Cambridge: Harvard University Press).

Kajiyama, Yuichi (1965), "Buddhist Solipsism: A Free Translation of Ratnakīrti's Saṃtānāntaradūṣaṇa" Journal of Indian Buddhist Studies 13: 435-520.

Metzinger, Thomas (2010), The Ego Tunnel (New York: Basic Books).

Nishitani, Keiji (2009), "The Standpoint of Zen" in Jay Garfield and W. Edelglass (eds.) Buddhist Philosophy: Essential Readings (New York: Oxford University Press), 93-102.

Perrett, Roy (2017), "Buddhist Idealism and the Problem of Other Minds" Asian Philosophy 27.1: 59-68.

Rudd, Anthony (2003), Expressing the World (Chicago: Open Court Press).

Shaw, Miranda (1987), "William James and Yogācāra Philosophy: A Comparative Inquiry" Philosophy East and West 37.3: 223-244.

Sprigge, Timothy (2006), The God of Metaphysics (Oxford: Oxford University Press).

Waldron, William (2003), The Buddhist Unconscious (London: Routledge Curzon).

Walshe, Maurice (1995), The Long Discourses of the Buddha (Somerville: Wisdom Publications). 